\title{
Depositional model of Volcaniclastic-Carbonate Facies of Sentolo Formation at Miocene
}

\author{
$1^{\text {st }}$ Hita Pandita ${ }^{1}, 2^{\text {nd }}$ Hill Gendoet Hartono ${ }^{2}, 3^{\text {rd }}$ Setyo Pambudi $^{3}, 4^{\text {th }}$ Winarti $^{4}$ \\ hita@sttnas.ac.id ${ }^{1}$ \\ Department of Geological Engineering, Institut Teknologi Nasional Yogyakarta, Indonesia
}

\begin{abstract}
Intercalation between carbonate and volcaniclastic rock are abundance in Java Island especially at southern part. Although this intercalation has long been recognized, very few studies into the depositional models of the intercalation have been undertaken. An ideal site for such a study of an ancient example is Sentolo Formation of Kulonprogo area in south central Java. The aim of this research is to understand the depositional models of Sentolo Formation. This research based of petrography, and stratigraphic analyze from many stratigraphic section of Sentolo Formation outcrop. The stratigraphic section have represented of distribution at northern, middle, eastern, and southern part of Sentolo Formation in Yogyakarta area. Result of this study is three possibility facies models of Sentolo Formation paleoenvironment. The models have distributed at northern, middle-western, and southeastern part. High volcanic activity have founded at northern part, even in middle to the western part are fine fraction of volcanic rocks, while no volcanic rocks at southeastern part. Result of this research is also possibility a reef system at Sentolo Formation separated with Jonggrangan Formation. The old concept said that origin of Sentolo Formation was connected with Jonggrangan Formation it must be review again, it caused no stratigraphic contact between Jonggrangan Formation and Sentolo Formation.
\end{abstract}

Keyword: Carbonate, volcanic, Sentolo Formation, Paleoenvironment

\section{Introduction}

Intercalation between carbonate and volcaniclastic rock are abundance in Java Island especially at southern part. They occurred since Miocene to present day. One of location which contains this intercalation is Sentolo Formation. This formation deposited in Middle Miocene to Upper Pliocene (Rahardjo, et al, 1995).

Sentolo Formation have been researched by many authors like Pandita, et al. (2016), Kadar (1985), and Pambudi et al, (1998). Although Sentolo Formation has been researched by many authors, the intercalation between carbonate and volcaniclastic rock had been not explain.

The aim of this research is to understand the depositional models of intercalation between volcanic deposited and limestone at Sentolo Formation. This study included sedimentary process and development of paleoenvironment. Another reason how was the depositional models of Sentolo Formation, and the last where was the location of Middle Miocene volcanoes.

The research area is situated in the Kulonprogo dome and Yogyakarta basin of south Central Java (Figure 1). The area lies between latitudes $07^{\circ} 41^{\prime} \mathrm{S}$ and $07^{\mathrm{O}} 56^{\prime}$ 'S and longitudes $110^{\circ} 10^{\prime} \mathrm{E}$ and $110^{\circ} 18^{\prime} \mathrm{E}$. The area is located at Kulonprogo, Sleman, and Bantul district. 


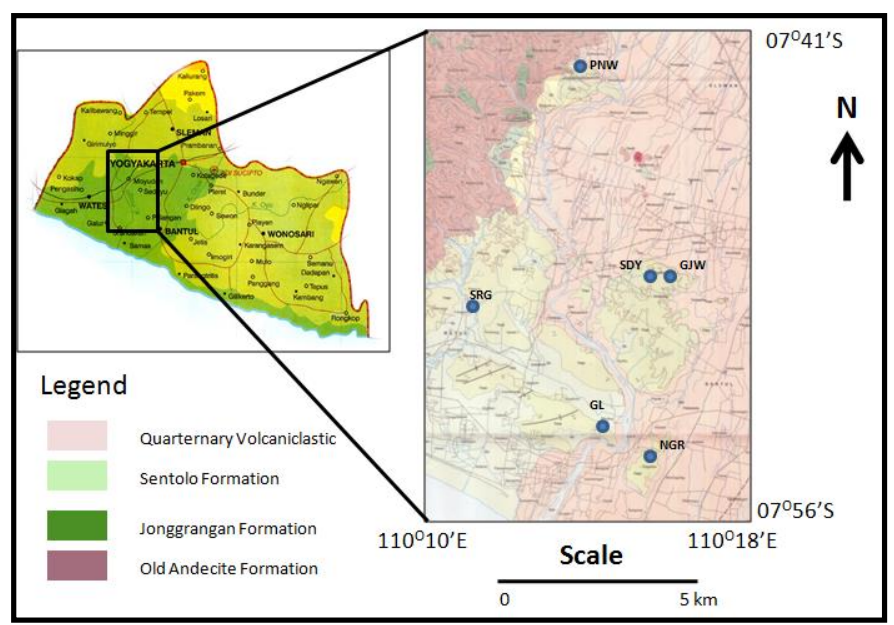

Figure 1. Research location, blue cirle are six stratigraphic section (Geological map from Rahardjo, et al, 1995).

\section{Methods}

During fieldwork, lithologies were systematically logged and sampled to establish stratigraphic sequence and facies variation across the area. Six stratigraphic sections have been recognized, they represented of the distribution of Sentolo Formation. Samples were returned to the ITNY where petrographic analyses and foraminifera analyses had undertaken. These analyses have been used to constrain the microfacies and age.

\section{Geological Setting}

The study area is located at eastern part of West Progo Dome based on the Bemmelen (1949) scheme (Figure 2). The research area has bordered by depression of Yogyakarta at eastern part, volcaniclastic present-day at northern part and Hindia Ocean at southern part. West Progo Dome built by active tectonic at Pliocene (Rahardjo et al., 1995). The first volcanic activity was rising at early Oligocene which built up of Ijo, Gajah, and Menoreh volcanoes. That volcanic have been known as Old Andecite Formation.

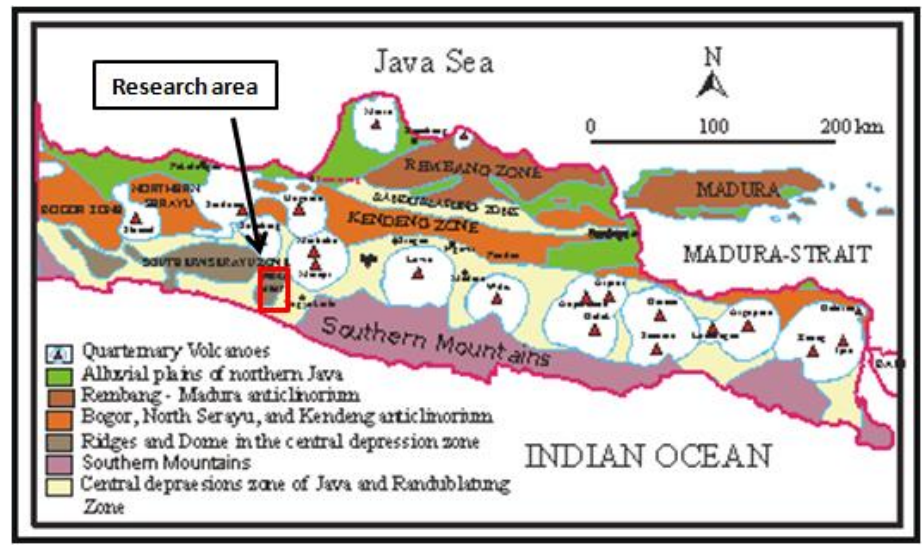

Fig. 2. Regonal Physiography of Central and East Java by Bemmelen (1949). 
The regional stratigraphical of West Progo Dome have been proposed by many authors (Table 1). The oldest is Nanggulan Formation which deposited at Eocene. Unconformable overlies of Nanggulan Formation is Old Andesit Formation (OAF) and consist of volcanic material origin at Early Oligocene. Different with many authors, Rahardjo et al. (1995) giving a name Kebo-Butak Formation for OAF. Overlies of OAF is Jonggrangan Formation consist of limestone and deposited at Early Miocene to Middle Miocene. Pandita and Hartono (2019) identified the lower part of the Jonggrangan Formation composed of sandstone, claystone and thin coal insertions. Conformable and interfingering have been proposed many authors to explain the stratigraphical contact between Jonggrangan and Sentolo Formation. Bemmelen (1949) explain both of them deposited at same time with different paleoenvironment. Sentolo Formation had been deposited at Early Miocene to Pliocene consist of intercalation volcaniclastic and carbonate rocks.

Table 1. Regional Stratigraphic of Kulon Progo from many researcher (Pandita and Hartono, 2019).

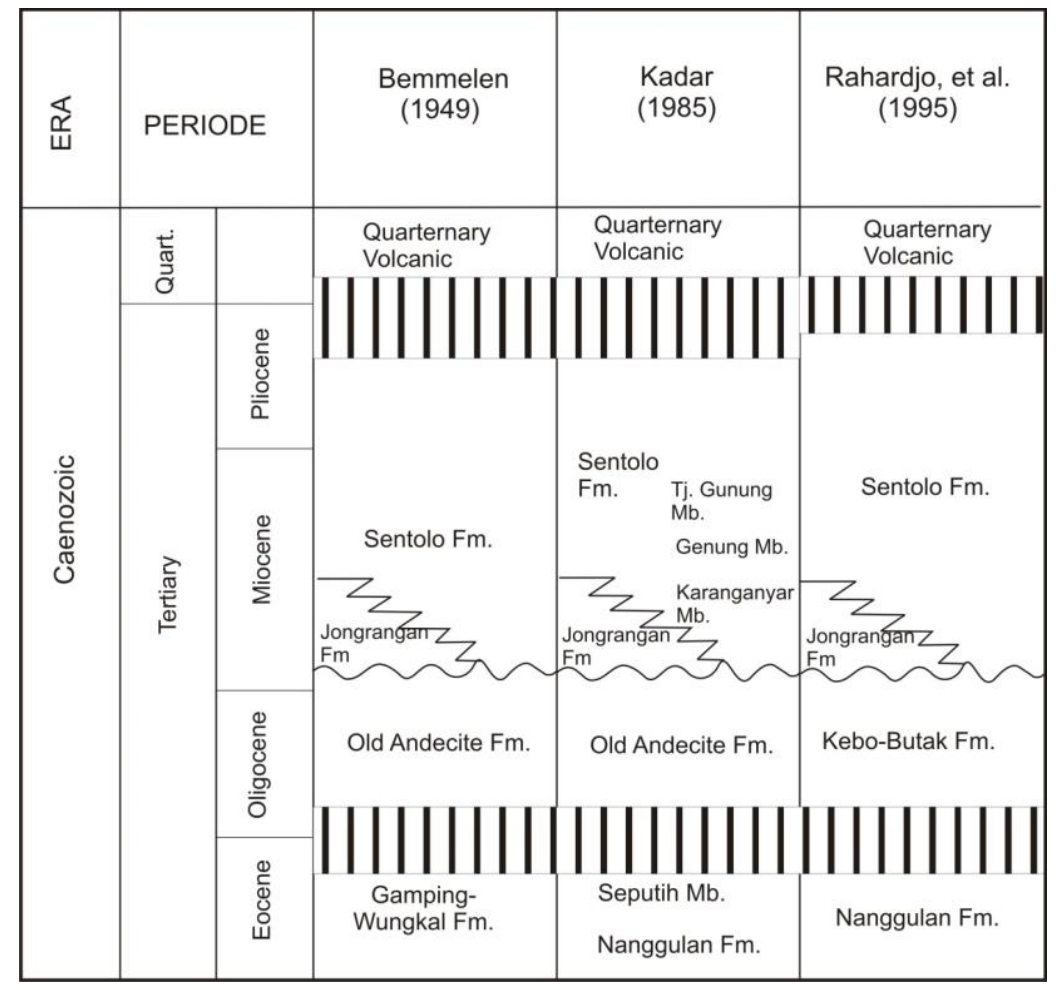

Regional tectonic of West Progo Dome is still debate by many authors. Bemmelen (1949) proposed this area is a part of South Serayu zone. West Progo Dome had been uplifted by undulating process. Different argue was proposed by Rahardjo, et al. (1995) that West Progo Dome uplifted at Late Pliocene together with origin of Yogyakarta depression.

Sribudiyani et al. (2003) suggested that West Progo was a part of East Java microplate. Both of them predicted three tectonic periods had been done at this area from Late Cretaceous to present day. From the end of Cretaceous to Early Eocene (70 - $35 \mathrm{ma}$ ) East Java microplate 
had been colliding to Sunda microplate. It caused the Cretaceous subduction to cease and uplifted the subduction complex, creating basin of Nanggulan Formation. The second period was creating at Oligocene to Early Miocene, it started a different trend of subduction. The subduction zone at second period located at south of Java. This period caused volcanic activity at West Progo basin creating Old Andesite Formation. Last period it come from Late Miocene to present day, it caused southwest-northeast strike slip trends.

\section{RESULT}

Six stratigraphic sections have been recognized (Figure 2), including 28 petrography and 30 micropaleontolgy analyses. The area is located at Kulonprogo, Sleman, and Bantul district.

\section{Gejawan Section (GJW)}

The section is located at Gejawan village south of street of Wates - Yogyakarta. It is about $8^{\text {th }} \mathrm{km}$ west part of Yogyakarta city. The area lies between latitudes $07^{\circ} 48^{\prime} 40$ ' $\mathrm{S}$ and $07^{\circ} 48^{\prime} 48^{\prime \prime} \mathrm{S}$ and longitudes $110^{\circ} 17^{\prime} 54^{\prime \prime} \mathrm{E}$ and $110^{\circ} 17^{\prime} 56^{\prime \prime} \mathrm{E}$. The section is located at eastern part of distribution of Sentolo Formation.

This section is consist two lithologies unit with thickness of section are 25 meters. The bottom part is limestone unit and upper part is intercalation limestone and calcareous tuff unit. The limestone unit are composed only wackstone, with thickness about $6 \mathrm{~m}$. Based of petrography analyses are composing abundance of planktonic foraminifera (Figure 3A). Based on Wilson facies models (Wilson, 1975), this unit possibility deposited at Basin plain. The intercalation between limestone and tuff unit was occure at middle part to upper part. The thickness of this unit approximally at $19 \mathrm{~m}$. At middle part tuffaceous limestone is composed of fossil $(6 \%)$, carbonate fragment $(25 \%)$, opaque minerals $(4 \%)$, micrite $(30 \%)$ and tuff (35\%) (Figure 3B). This part possibility deposited at open sea shelf facies based of Wilson facies models.
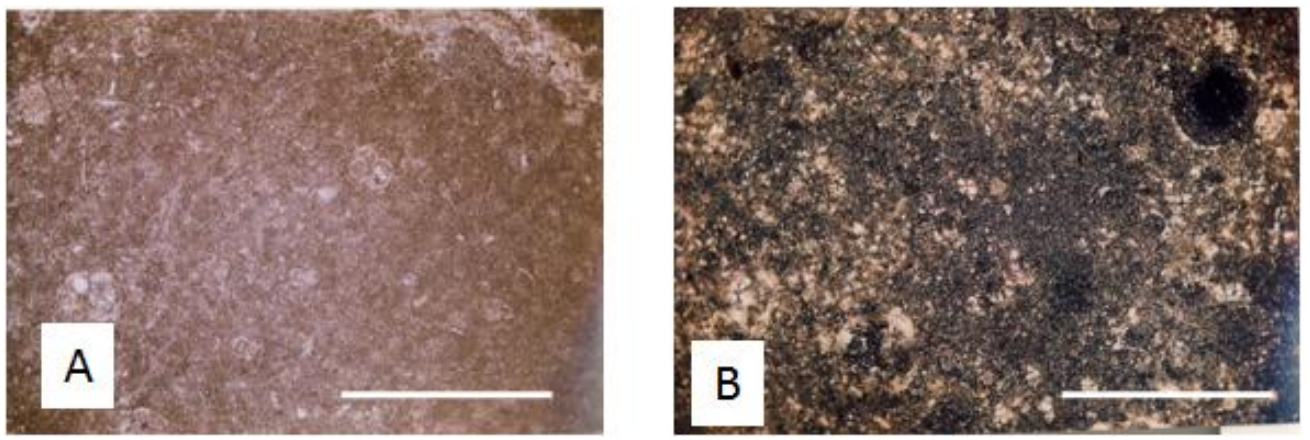

Fig. 3. Petrography thin section from Gejawan: A) bottom part of Gejawan section showing a foraminiferal wackestone, B) Tuffaceous limestone from middle part of Gejawan Section. White line is scale bar $(1 \mathrm{~mm})$.

The upper part are tuff unit, that is dominated calcareous tuff. Based of petrography analyses tuff is consist of fossil (12\%), feldspar (3\%), opaque minerals (13\%), micrite (7\%) and tuff $(65 \%)$. Based of composed of carbonate this rocks possibility deposited at deep shelf margin facies.

Based on the fossil content of plangtonic foraminifera, the rock series in the Gejawan cross section is thought to have formed in the Middle Miocene (N13 - N16). This is 
characterized by the appearance of Globigerina praebulloides, Globigerine nepenthes, Orbulina universa and Globorotalia acostaensis.

\section{Serang Section (SRG)}

The section is located at Serang stream in Pengasih village. It is about $3^{\text {th }} \mathrm{km}$ northeast part of Wates town. The area lies between latitudes $7^{\mathrm{O}} 50^{\prime} 08^{\prime \prime} \mathrm{S}$ and longitudes $110^{\circ} 10^{\prime} 16^{\prime \prime} \mathrm{E}$. The section is located at western part of distribution of Sentolo Formation.

This section is consist of limestone unit with thickness of section are 10 meters. The bottom part is characteristic by foraminiferal packestone. The upper part was changes to intercalation of foraminiferal packestone with tuffaceous limestone (Figure 4). Chondrites and Thallasinoides are present at bottom part, and cylindrichnus at upper part. Based of petrography analyses the limestone is composed of packestone to mudstone. This unit were depositing at deep shelf margin based Wilson facies models (Wilson, 1975).
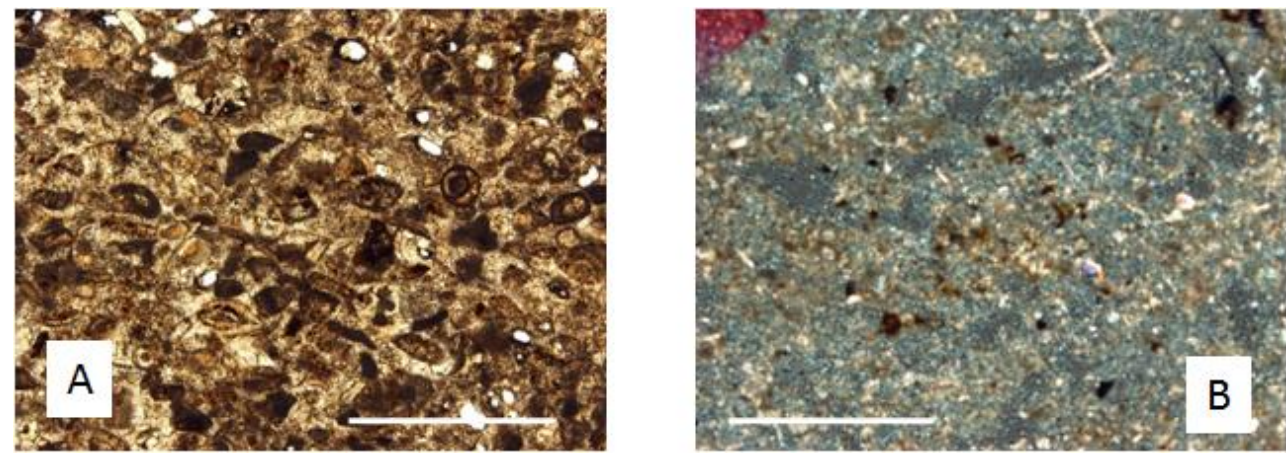

Fig. 4. Petrography thin section from Serang: A) bottom part of Serang section showing a foraminiferal Packestone, B) Tuffaceous limestone from upper part of Serang Section. White line is scale bar $(1 \mathrm{~mm})$.

Based on the fossil content of plangtonic foraminifera, the rock series in the Serang cross section is thought to have formed in the Early Pliosen (N19). This is characterized by the appearance of Pulleniatina obliquiloculata, Globorotalia miocenica, and Sphaeroidinella subdehiscens.

\section{Sedayu Section (SDY)}

The section is located at Sedayu village south of street of Wates - Yogyakarta. It is about $10^{\text {th }} \mathrm{km}$ west part of Yogyakarta city. The area lies between latitudes $7^{\circ} 49^{\prime} 40,6^{\prime \prime} \mathrm{S}$ and $7^{\circ} 49^{\prime} 46,5$ 'S and longitudes $110^{\circ} 16^{\prime} 26,8^{\prime \prime} \mathrm{E}$ and $110^{\circ} 16^{\prime} 23,3$ '”. The section is a middle part of distribution of Sentolo Formation.

This section is consist intercalation of tuffaceous limestone and limestone unit. Thickness of this section is 15.2 meters. At bottom part tuffaceous limestone was dominated, and gradually changed to grainstone at upper part. Large foraminifera were present at upper part together with coral's fragment (Figure 5).

Three paleoenvironment have developed during deposition. At bottom part was deposited at basin facies, and changed to deep shelf margin at middle part, last changed into foreslope at upper part. 
Based on the fossil content of plangtonic foraminifera, the rock series in the Sedayu section is thought to have formed in the Late Miocene to Early Pliosen (N17-N20). This is characterized by the appearance of Globorotalia merotumida, Globorotalia tumida, and Sphaeroidinella dehiscens.
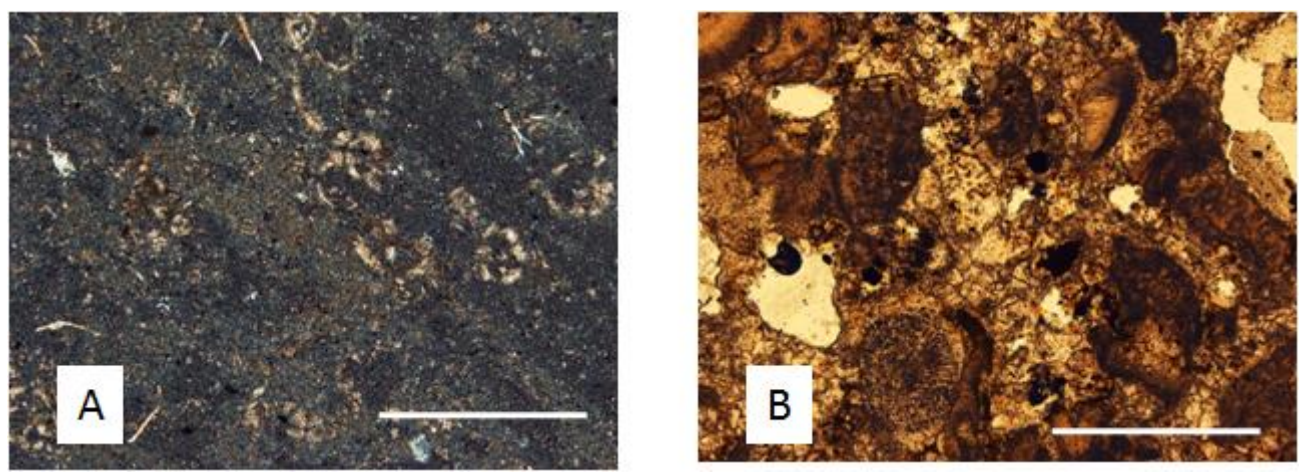

Fig. 5. Petrography thin section from Sedayu: A) bottom part of Sedayu section showing a Tuffaceous mudstone, B) Grainstone from upper part of Sedayu Section. White line is scale bar (1 $\mathrm{mm})$.

\section{Guluhredjo Section (GL)}

The section is located at Guluhredjo village near of Guluhredjo Elementary School (SD Guluhredjo I), located at Sentolo-Srandakan way. The area lies between latitudes $7^{\mathrm{O}} 54$ ' 48 ' $\mathrm{S}$ and $7^{\circ} 54^{\prime} 48^{\prime \prime S}$ and longitudes $110^{\circ} 15^{\prime} 42^{\prime \prime} \mathrm{E}$ and $110^{\circ} 15^{\prime} 32^{\prime \prime} \mathrm{E}$. The section is located at southern part of distribution of Sentolo Formation.

This section is composing limestone interbedded. The thick of Guluhredjo section are 20.09 meters and consist of wackestone and foraminifera packstone (Figure 6). Planktonik foraminifera are abundant. Cross laminated structure is occurring at upper part. This unit has deposited at deep shelf margin.
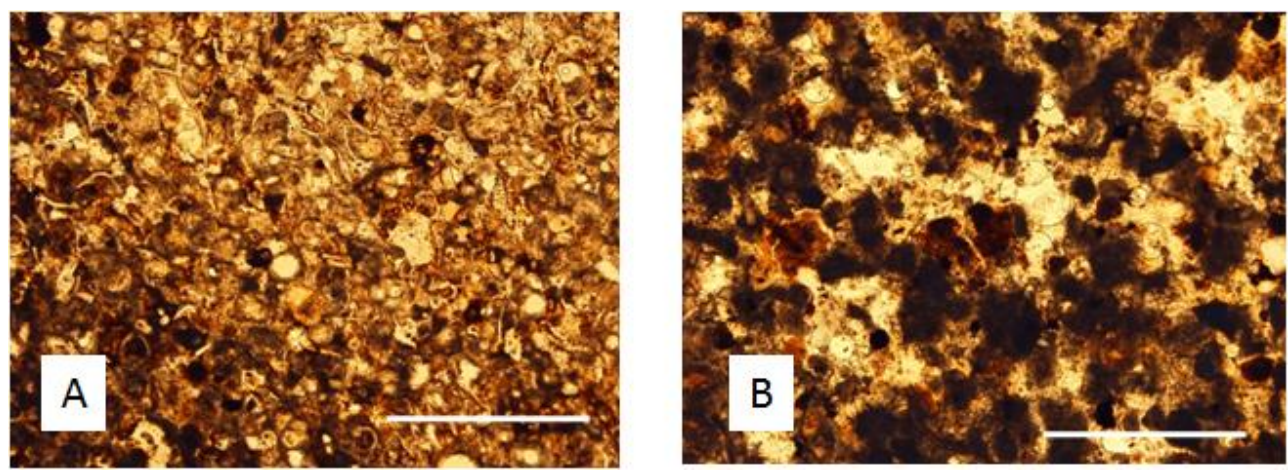

Fig. 6. Petrography thin section from Guluhredjo: A) bottom part of Guluhredjo section showing a Foraminferal packestone, B) Wackestone from upper part of Guluhredjo section. White line is scale bar $(1 \mathrm{~mm})$. 
Based on the fossil content of plangtonic foraminifera, the rock series in the Guluhredjo section is thought to have formed in the Early Pliosen (N19). This is characterized by the appearance of Globorotalia miocenica, and Pulleniatina obliquiloculata.

\section{Ngaran Section (NGR)}

The section is located at Ngaran village about $2 \mathrm{~km}$ west of the way from Bantul to Samas. The area lies between latitudes $7^{\circ} 55^{\prime} 40^{\prime} \mathrm{S}$ and $7^{\mathrm{O}} 55^{\prime} 43^{\prime \prime} \mathrm{S}$ and longitudes $110^{\circ} 17^{\prime} 46^{\prime} \mathrm{E}$ and $110^{\circ} 17^{\prime} 38^{\prime \prime}$ E. The section is located at southeastern part of distribution of Sentolo Formation.

This section is consist limestone unit. The thick of Ngaran section are 9.2 meters and consist of wackestone and packestone. Planktonik foraminifera are abundant. Based of petrography analyses, volcaniclastic matrix are present as tuff at upper part. Limestone unit has deposited at deep shelf margin.
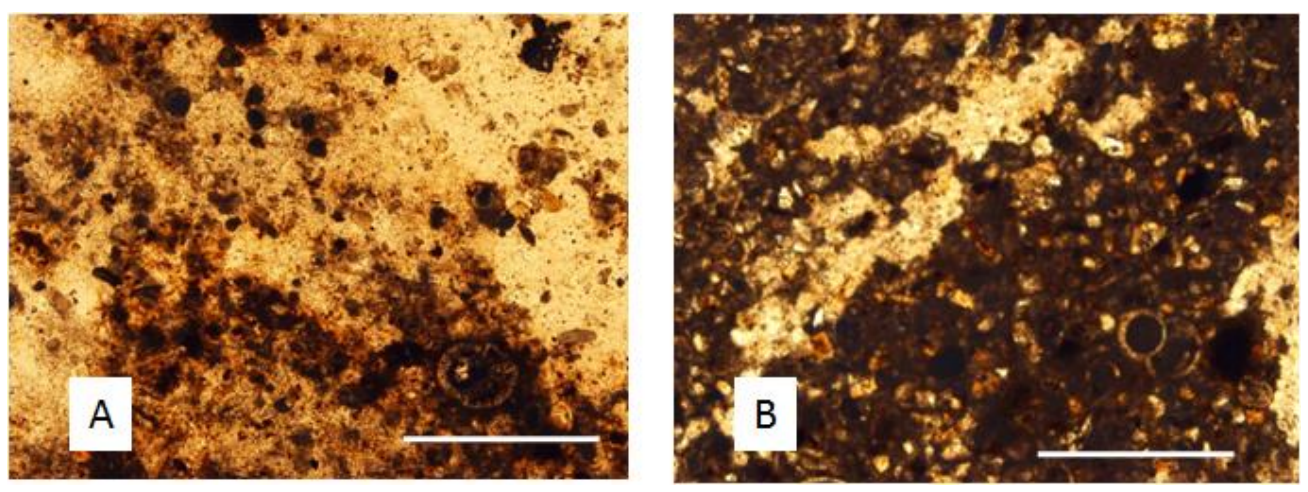

Fig. 7. Petrography thin section from Ngaran: A) bottom part of Ngaran section showing a Foraminferal wackestone, B) Foraminifera packestone from upper part of Ngaran section. White line is scale bar (1 $\mathrm{mm})$.

Based on the fossil content of plangtonic foraminifera, the rock series in the Guluhredjo section is thought to have formed in the Early Pliosen (N19). This is characterized by the appearance of Globorotalia miocenica, and Pulleniatina obliquiloculata.

\section{Penewon Section (PNW)}

The section is located at Penewon village about $2 \mathrm{~km}$ west of the way from Nanggulan to Magelang. The area lies between latitudes $7^{\circ} 41^{\prime} 08^{\prime \prime} S$ and $7^{\circ} 41^{\prime} 12^{\prime \prime \prime} S$ and longitudes $110^{\circ} 14^{\prime} 28^{\prime \prime} \mathrm{E}$ and $110^{\circ} 14^{\prime} 26^{\prime \prime}$ E. The section is located at northern part of distribution of Sentolo Formation.

This section is composed by tuffaceous limestone unit. The thick of Penewon section are 29.47 meters and consist of intercalation between foraminiferal packestone and grainstone. Planktonik foraminfera abundance at lower part, and large foraminifera were present together with coral fragment at the upper part (Figure 8). Based of petrography analyses, volcaniclastic fragment are present with size less than $0.5 \mathrm{~mm}$, occure from lower to upper part. 

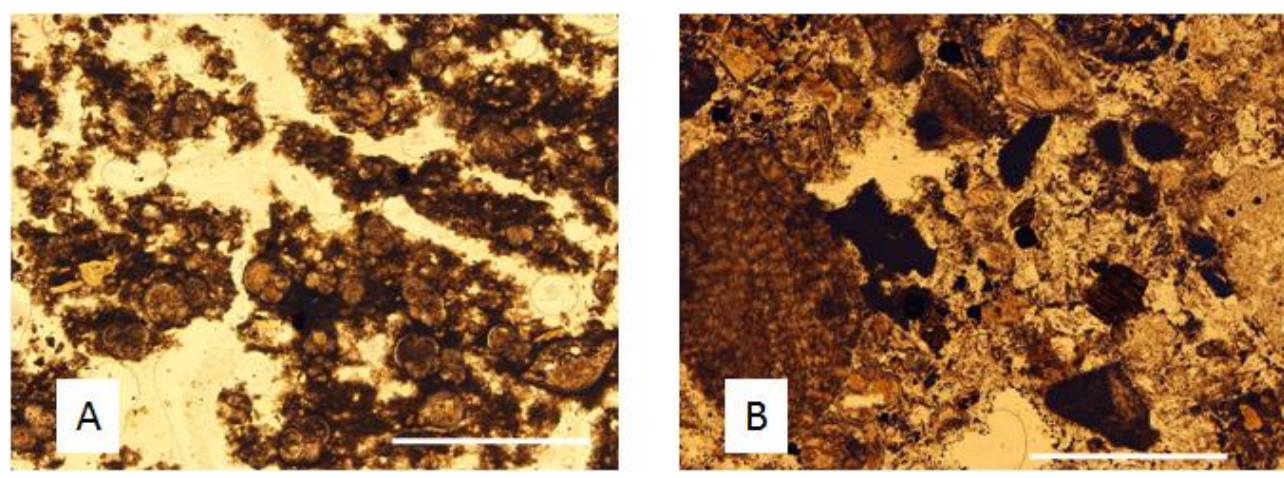

Fig. 8. Petrography thin section from Penewon: A) bottom part of Penewon section showing a Foraminferal packestone, B) Grainstone from upper part of Ngaran section and conatin some lithic fragment. White line is scale bar $(1 \mathrm{~mm})$.

Based on petrography thin section analysisi, depositional environment of Penewon section looked different. The lower part of Penewon section has deposited at deep shelf margin, then changed to fore slope at upper part.

Based on the fossil content of plangtonic foraminifera, the rock series in the Penewon section is thought to have formed in the Early Miocene (N5-N8). This is characterized by the appearance of Praeorbulina glomerosa, Globigerinoides diminutus and Globorotalia kugleri.

\section{Discussion}

\section{Volcaniclastic evidence at Sentolo Formation}

During the depositional of Sentolo Formation volcanic activity still influence of sedimentary process. As today, this volcanism was associated with the northwards subduction of the Indo-Australian Oceanic Plate to the south of the area. The volcaniclastic sediment at this area could be defined at two types of depositional environment.

First type was developing at northern part. Ash and lapili were falling as air fall into basin. It's look at upper part of Penewon section, which contain much lapili and lithic tuff fragment. First type was deposited at upper of medial facies (Bogie \& Mackenzie, 1998).

Second type was developing at western and southeastern part (Fig 5), were only ash fall. Based of ash fall identified this type was deposited at distal facies (Bogie \& Mackenzie, 1998). It's looked at sample from Gejawan, Ngaran and Guluhredjo.

\section{Depositional Environment of Sentolo Formation}

The Sentolo Formation was deposited at two models depositional. The carbonate platform was origin at foot of volcanic island arc. The Middle Miocene volcanic island arc location is still debate. We proposed a hypothetical location at Godean area. Diorite is finding at Godean area, but the age of rock not identified (Rahardjo, et al, 1995).

The first models of depositional of Sentolo Formation are located at northern part. West of the volcanically active island-arc, in medial volcanic facies carbonate platform develop under moderate energy condition. Volcaniclastic sediment derived from the volcanic-arc east of the area mixed with turbidity current from carbonate platform at west of the area (Figure 9). 


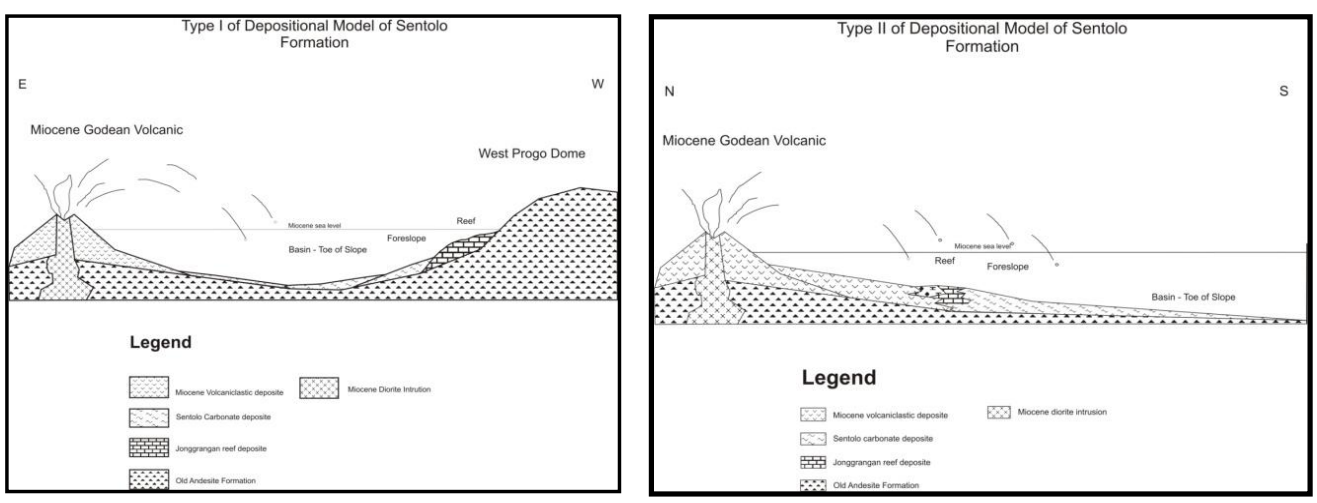

Fig. 9. Left picture is depositional model of Sentolo Formation at northern part, right picture is depositional model at southern part.

The second models are located at western to eastern and southern part of Sentolo Formation distribution. South of the volcanically active island-arc, in medial volcanic facies carbonate platform develop under low to moderate energy condition. Ash fall derifed from the volcanic-arc north of the area mixed with suspend and traction current from carbonate platform at surrounding area (Figure 9).

\section{Conclusion}

While sites of intercalation of volcaniclastic and carbonate sedimentation are common in Java, research in these paleoenvironment has been neglected. The Middle Miocene Sentolo Formation of West Progo Dome offers an opportunity to study an ancient example of such an environment.

This study indicates two models depositional of Sentolo Formation combine with two volcaniclastic facies. First models are deposited at medial volcaniclastic facies in deep shelf margin carbonate facies. Second models are deposites at medial volcaniclastic facies in open shelf margin carbonate facies.

\section{Acknowledgements}

This research was doing by fund research from Directorat General of Higher Education of The Indonesian Ministry of Education in fiscal year 2008-2009 and Minstry of Research and Higher education Indonesia in fiscal year 2018. Laboratory analyses were undertaken at ITNY (before STTNAS) laboratory. 


\section{References}

[1] Bemmelen R.W. van, 1949. The Geology of Indonesia. The Hague, Martinus Nijhoff, vol. IA.

[2] Bogie, I., and Mackenzie, K.M., 1998, The Application of a Volcanic Facies Models to an [3] Andesitic Stratovolcano Hosted Geothermal System at Wayang Windu, Java, Indonesia, Proceeding 20 ${ }^{\text {th }}$ NZ Geothermal Workshop, pp 265-276.

[4] Kadar D, 1986, Neogene planktonic foraminiferal biostratigraphy Of The South Central Java Area Indonesia, Geological Recearch and Development Centre, Bandung.

[5] Pambudi, S., Sutarman, and Budiadi, E.V., 1998, Pola Sedimentasi Formasi JonggranganFormasi Sentolo di Gn. Kucir - Gn. Dalanggung Barat, Kec. Samigaluh dan Kec. Kalibawang, Kab. Kulonprogo. Jurnal Teknologi Nasional, vol. II No. 1, Oktober, STTNAS Yogyakarta.

[6] Pandita, H. and Hartono, H.G., 2019, Identification and Stratiraphic Position of Mollusk Type Locality at West Progo Stage, Journal of Geoscience, Engineering, Environment, and Technology Vol 04 No 02, DOI: 10.25299/jgeet.2019.4.2.2682

[7] Pandita, H., Pambudi, S., and Winarti, 2016, Kajian Biostratigrafi Dan Fasies Formasi Sentolo di Daerah Guluhrejo dan Ngaran Kabupaten Bantul Untuk Mengidentifikasi Keberadaan Sesar Progo, Proc. Seminar Nasional UNPAD, Bandung

[8] Purnamaningsih, S. and Pringgoprawiro, H., 1981, Stratigraphy and Planktonic Foraminifera of the Eocene-Oligocene Nanggulan Formation, Central Java, Geol. Res. Dev. Centre Pal. Ser. N. 1, p. 9-28, 5 pls., Bandung, Indonesia.

[9] Rahardjo, W., Sukandarrumidi, and Rosidi, H.M.D., 1995, Peta Geologi Lembar Yogyakarta, Jawa, Nomor Lembar Peta 1408-2, Pusat Penelitian dan Pengembangan Geologi, Bandung, Indonesia.

[10] Sribudiyani, Muchsin, N., Ryacudu, R., Kunto, T., Astono, P., Prasetya, I., Sapiie, B., Asikin, S., Harsolumakso, A.H., Yulianto, I., 2003, The Collision of the East Java microplate and its implication for hidrocarbon occurences in the East Java Basin: $29^{\text {th }}$ Proceeding Indonesian Petroleum Association, Jakarta, 2003, G-085.

[11] Wilson, J.L., 1975, Carbonate Facies in Geologic History, Springer-Verlag, Berlin. 